\title{
Planning Failure of Satellite Town: A Case Study of Korangi, Karachi-Pakistan
}

\author{
TANIA ALI SOOMRO* AND MOHSIN ALI SOOMRO** \\ RECEIVED ON 12.05.2017 ACCEPTED ON 21.08.2017
}

\begin{abstract}
The Satellite town of Korangiis part of the 'Greater Karachi Resettlement Plan' along with other satellite towns of Landhi and New Karachi proposed by the Greek Architect Constantinos Apostolou Doxiadis in 1958. It is located in southern part of Karachi next to the Arabian Sea at latitude: $24^{\circ} 49^{\prime}$ and longitude: $67^{\circ} 7^{\prime}$. It is considered as one of the major post-independence urban regeneration projects. The actual plan of Doxiadis was supposed to be developed as self-sufficient satellite town for refugees (from Indian sub-continent partition) with the provision of employment through industries and commercial areas along with residential settlement. This research revolves around the planning strategies adopted by the architect influenced by the indigenous way of living. The analysis is based upon the main proposition of the Greater Karachi Resettlement Plan that aimed to develop industrial activity in the satellite towns of Landhi-Korangi and North Karachi freeing the central Karachi from low income groups (poor) and from environmental degradation. From here began the multiple issues mainly the transportation troubles of city, as these settlement towns were positioned at least 25 Kilometer off the city centre which probably was the only working hub for most of people then. This eventually led to the failure of the plan leaving behind the inhabitants with economic pandemonium. The objective of this research is to understand the issues related to the existing satellite town and the reasons for its decline; not growing on the pace of what it was assumed to develop. The paper also focuses on the stated argument of the failure of this massive relocation plan and its impacts on rest of the city.
\end{abstract}

Key Words: Satellite Town, Korangi, Greater Karachi Resettlement Plan, Constantinos Apostolou Doxiadis, Planning Strategies.

\section{INTRODUCTION}

$\mathrm{T}$ he concept of Satellite town originated from the Garden City theory by a British social activist Ebenezer Howard in early 20th century. He believed that the over spilling population and the employment could be resettled to a nearby actual city relieving the inner city from a constant growing pressure.
The concept of having smaller towns around the actual city that resemble a satellite around the planet emerged from his theory and ever since the term has been widely used. A satellite town can be referred to as a limited sized settlement planned to ease demand of expansion on an existing city or a settlement. 
A satellite town is mostly self-contained in services. However it is dependent on the host-city/parent city for major services. It is distinct from production-satellite settlements established in many parts of the world to house large industrial complexes or the commercial activity centers, and the consumer-satellite settlements which provide basic residential facilities with very limited facilities. There are many precedents of satellite towns in the world. In Germany, the satellite town of Detmerode was established near Wolfsberg to support Wolkswagen manufacturing facilities. Similarly, Gurgaon, Noida and Ghaziabad were established to ease housing pressure on New Delhi in India. A similar example can be seen in the satellite town of Korangi in Karachi, Pakistan.

The study of the planning failure of the satellite town of Korangi elaborates on earlier research on the success and challenges of planning satellite towns. This research aims to improve the understanding of the limitations in urban planning of large cities and highlight the factors contributing to failure and success in achieving the desired objectives. The topic remains relevant to present day needs of Pakistan as the country struggles to provide housing solutions to its burgeoning population.

\section{LITERATURE REVIEW}

Pakistan came into existence on the world map on August 14, 1947. Earlier it used to be part of the greater British Raj together with the present day countries of India and Bangladesh. The history of the city of Karachi dates to 1729 when it emerged as fortified port settlement. It used to be a small fishing village at the time when it was occupied by the British in 1839 and with this annexation a new era of development and construction started. The city of Karachi, then capital and the only economic hub of the new born Pakistan faced very critical problems in 1947 during Indian Subcontinent partition phase. Major of all was the land development. From a port town it had suddenly to become an administrative and reception center for the immigrants from India.

Since a century, there had been number of Karachi development schemes even before partition of subcontinent in 1947. Due to the increasing number of population and the changing economic, political and social institutions Karachi have accommodated a handful of satellite towns that are socio-economically tied to the urban center of the city yet have independent structure connected by the commuting measures. The northern end of the city has extended to the satellite towns of North Nazimabad, Korangi, Site area, Orangi and recently developing Bahria town and DHA city etc.

\subsection{The Precedents of the Urban Development in Karachi}

The first known scheme of the urban development was prepared by Miram in 1922 [1] and realized effectively. The second plan was prepared by Colonel Thomas in 1946 [1] just a year before partition and was declared impractical as the city's population increased unexpectedly due to migration of refugees. Soon in 1949, a newly formed government commissioned the Swedish firm MRV (Merz Randal Vatten) commonly known as MRV associates, to prepare a master plan for the development of Karachi. The MRV Plan suggested keeping the city administration separated from the historic city centre to the northern part to form a new capital, and connected through rapid transportation system. High rise mass housing residential blocks along Lyari River were proposed to settle the refugees, with the SITE area as a major industrial center. The key thought at the back of this scheme was to make the new settlements economically self supportive. In 1958 Martial Law Government decided to move the capital administration to a new city Islamabad. In the meanwhile, apart from refugees, people started migrating from other cities to

Mehran University Research Journal of Engineering \& Technology, Volume 37, No. 1, January, 2018 [p-ISSN: 0254-7821, e-ISSN: 2413-7219] 
Karachi for economic reasons. As a result population increased and many squatter settlements emerged within the city. The MRV plan could not meet its targets due to these reasons. The data base upon which the plan was based was later identified to be inadequate; moreover the capital was shifted from Karachi to Islamabad thus making the new Karachi district seemed to be a pointless thought [2].

In 1958, the Government of Pakistan hired the Greek architectural firm Doxiadis Associates to develop new satellite towns to house low income groups as part of 'The Greater Karachi Resettlement Plan’ for the city. The towns were designed as self-sufficient centers in themselves but the overall supporting context, in which these self-sufficient centers existed, was missing. Due to the slow pace development of industrial and commercial sector and the lack of transportation to connect the existing city center (employment hub then) and the new satellite towns subjected the plan to be incapable of realizing the ground realities and eventually failed. 20 years later another master plan was prepared by the Karachi Development Authority, with the financial assistance of United Nations Development Program. It was titled as Karachi Development Plan 1974-1985. It was a major exercise in the field of regional planning that covered the total territory of Karachi spread over an area of 7,600 square miles [3]. Due to the management and other issues this plan too was not realized entirely except for few parts.

\section{MATERIALS AND METHOD}

The process of acquiring relevant data was rather time taking. Due to uncertainty about the sources and the amount of information available, a number of archives and offices in the city of Karachi were visited. It was not possible to get the relevant information in first visit, therefore, eight visits had to be made to certain libraries/ archives to acquire access to the data. Entire data was compiled and an analysis based on that information was developed by the authors. All the data acquired from other sources is used with due credits and copyrights. Data other than that shared in this paper is based on the personal experiences and the discussions with the relevant experts: senior faculty members at Department of Architecture and Planning, NED University of Engineering \& Technology, Karachi, Pakistan, and University of Leuven, Belgium, regarding various technical aspects and is developed by the authors.

\subsection{The Greater Karachi Resettlement Plan: An Argument}

In 1958, General Ayub Khan established military rule in Pakistan. He along with his minister for refugee rehabilitation and housing, General Azam Khan decided to discourage refugees and the low income/ working group migrating from other areas of Pakistan to live within the city center and decided to develop a new settlement town for them. He aimed to alleviate poverty from the city and resolve the problems of the shelter less muhajir families in the former capital city within six months. This was the first time Karachi was so widely bifurcated with respect to the income groups into the rich and poor. Constantinos Apostolou Doxiadis (The man who ended up planning the new capital city of Islamabad later in the 1960s), Greek planner, was hired to prepare what is known as the Greater Karachi Resettlement Plan today. Layout of the satellite towns along with the parent city is shown in Fig. 1. The plan consisted of developing two low income satellite towns, Landhi-Korangi to the east and New Karachi to the north of the city at a distance of about 25 kilometer from the city centre. It was considered the first attempt of resettling 30,000-40,000 families, addressing the changing demographic patterns in the city resulted due to the pressure of not only refugees but also the rural urban migration [4]. 
As displayed in the map in Fig. 2 phase-one of the plan included to create new townships out of Karachi in Korangi. After site selection a vast land survey was carried out. According to that survey of Karachi in 1959, it was declared that 119,000 homeless families were living in the city centre. Out of these only 19,000 were locals, the rest being refugees from India. 55\% of these lived in shacks and $43 \%$ in semi-permanent structures with least accessible hygienic and environmental conditions. Only a handful of families lived in appropriate houses and were privileged with the basic provisions of life [5].
Based on that data base, plan estimated that in coming 15-20 years Karachi would require 500,000 housing units and it undertook to actually build 300,000 of these for the poor in form of low rise high density mass housing. Initially, 45,000 one-room nuclear houses were planned, complete with all services such as connections for water, electricity and sewerage. Till 1964 only 10,000 units were built and allotted on very subsidized installment to the designated families. The industrial estates were planned as integral part of the satellite town plans and industrialists/ investors were offered incentives to invest

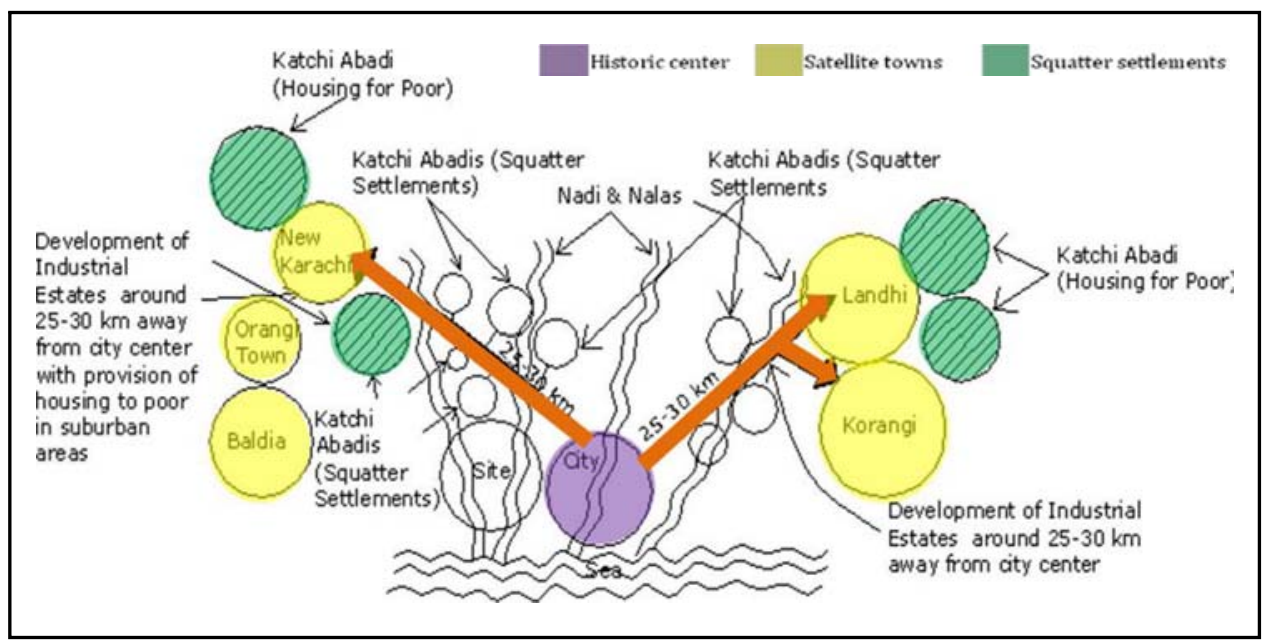

FIG. 1. PROPOSED RECOMMENDATIONS OF THE GREATER KARACHI RESETTLEMENT HOUSING PLAN 1956-1958 [1]

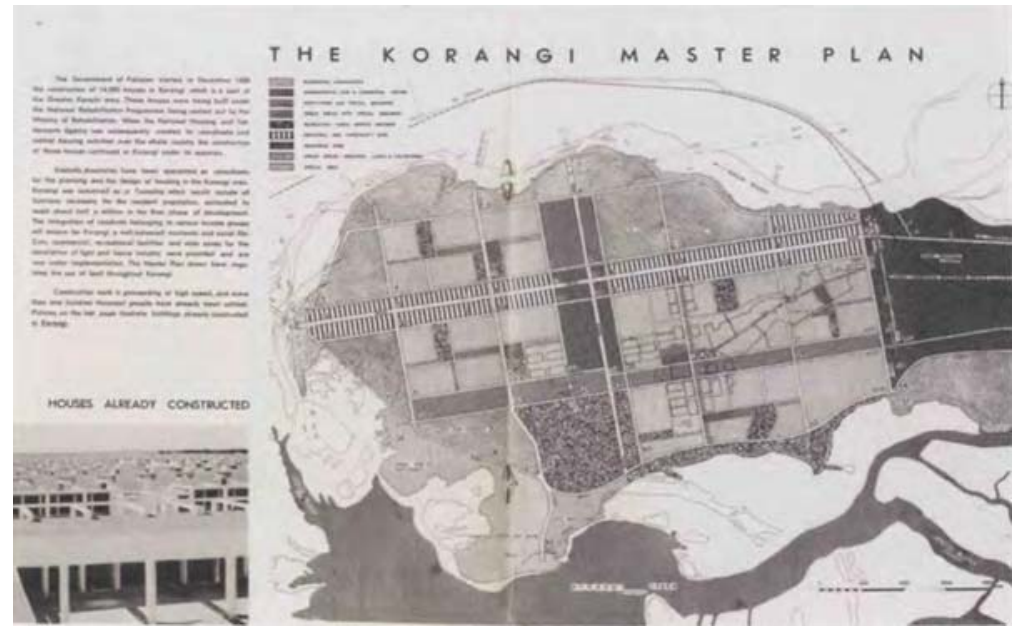

FIG. 2. GREATER KARACHI RESETTLEMENT HOUSING PROGRAM, MAP PUBLISHED IN BROCHURE, 1962 [6]

Mehran University Research Journal of Engineering \& Technology, Volume 37, No. 1, January, 2018 [p-ISSN: 0254-7821, e-ISSN: 2413-7219] 
there [7]. The main idea was to mark these towns the selfsufficient settlements. It was considered that the inhabitants of the new townships would be provided jobs in the proposed industrial estates and as a result Korangi and New Karachi would become independent satellite towns.

The government further undertook to subsidize $30 \%$ of this development. The rest was to be recovered from the users in easy installments. However, the whole planning did not turn to what it was assumed to be. Slow pace industrialization caused deficiency of employment and thus owners of the new houses were unable to pay their installments which were supposed to finance the continuation of the further housing process.

The Greater Karachi Resettlement Plan had a number of important outcomes on Karachi in social, physical and economic terms. Inner city refugee and squatter settlements were bulldozed and the residents were forcibly moved to the houses in new satellite towns. The plan converted a high density multi-class and culturally diverse city to a low density sprawl with the poor living far away from the city and the rich in its immediate vicinity. This created massive transportation crisis. Thus by 1964 the program was abandoned and shut down.

\section{RESULTS AND DISCUSSION}

\subsection{Understanding Planning of Korangi}

The satellite town of Korangi was planned as a place where poor could thrive. It was designed with the function of accommodating the population driven out of the inner city of Karachi and the post partition rural migrants. Later it was also supposed to house the third category of people, the future industrial laborers. Korangi was designed as one of the self-contained settlements planned by Doxiadis's human settlement approach. It was part of the general economic plan of Pakistan to manage with the sudden growth of inhabitants of Karachi from 0.5-2 million during the period of 1947-1958 [8]. Zoning was formulated by appropriate land-use planning which separated one set of land use from the other.

Various urban functions were addressed through different grid sizes. Each zone such as the residential, commercial, health care and the education synchronized with the building height,density, and similar characteristics, or some combinations of these.

The amenity plots, educational, public squares and the markets were planned centrally within each housing zone to cater the needs of inhabitants evenly. Pedestrian and the vehicular movement systems were considered equally important. The vehicular roads stretched over primary, secondary and tertiary networks that were wide enough to avoid traffic congestions. The planning of Korangi was an attempt to preserve a human scale. Fig. 3(a-b) low rise, high density planning was the most significant attribute of Doxiadis planning in Korangi. The precise system of dimensions and proportions were applied so as the building height was restricted to four stories maximum.

The housing blocks were designed in a standardized nuclear format as shown in the map given in Fig. 4(a-b). Each nuclear house-type was designed with functional aesthetics. Front and back of each house was left open for the green spaces knowing the fact that shade from plants would keep away the heat. Also within each house a central courtyard for household activities was provided which reflected the cultural sensitivity as well as the ideas moved by the local climatic conditions. The main façades were provided with reinforced concrete screens which imitated traditional wooden windows screens which were effort to achieve a balance in design with the local climatic condition [8]. In this age of energy shortages Doxiadis

Mehran University Research Journal of Engineering \& Technology, Volume 37, No. 1, January, 2018 [p-ISSN: 0254-7821, e-ISSN: 2413-7219] 
foresighted mind designed buildings as climate friendly to work well in Karachi's intense heat. He also sought to learn from old South Asian homes, many of which were surrounded by verandas, or covered porches, and were installed with screens that kept the brutal sun and monsoon rains away from the walls as Fig. 3(b). He opposed importing Western construction practices being too expensive; he proposed to build houses with sundried bricks, which the local women in rural villages could earn a living by making [9].
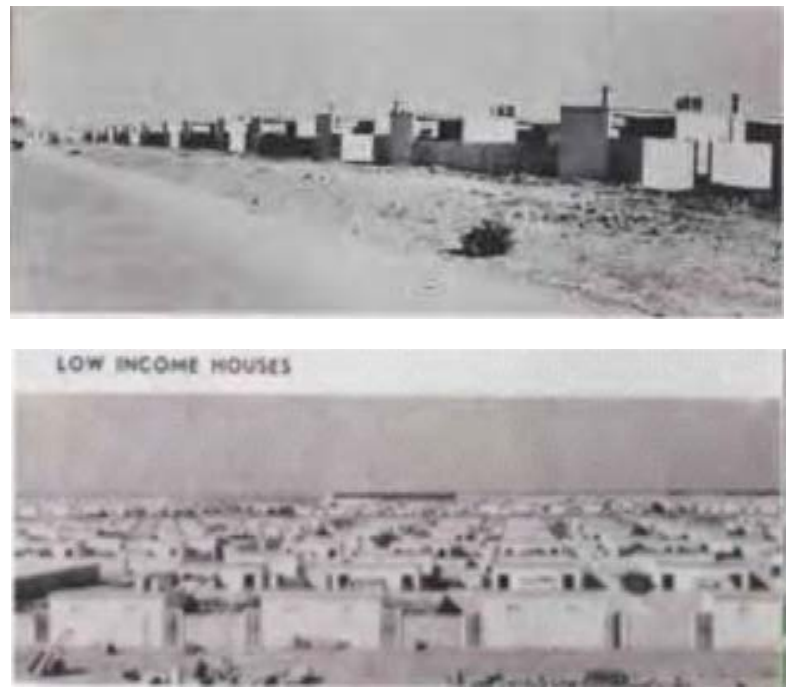

FIG. 3(a). TOP AND BOTTOM) IMAGES OF LOW RISE HIGH DENSITY MASS HOUSING

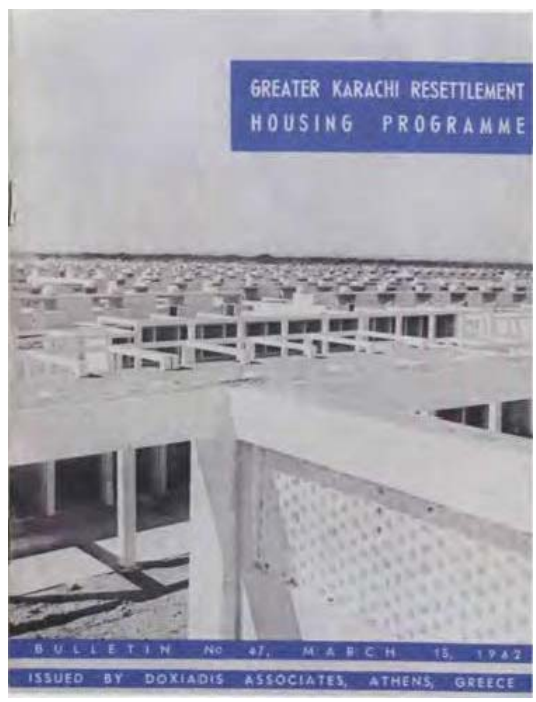

FIG. 3(b). CLOSER VIEW OF THE SCREENS INSTALLED IN THE WALLS [6]
The inclusive and the modernist approaches followed in planning were inspired by the indigenous cultural and contextual understanding. The relationship between various attributes such as nature and urban structures, use of local styles and materials and technology were the most important steps towards the sustainable modern approach followed by Doxiadis.

If people no longer live close to their jobs, then jobs would have to move closer to them. Followed by the idea, Doxiadis proposed a 12 kilometer long and 840 meter wide east-west strip of 'industrial' plots. The interdependent design of the industrial, institutional and civic infrastructure was designed to provide an opportunity for the consistent development of the several residential sectors.Each residential sector constituted of a main

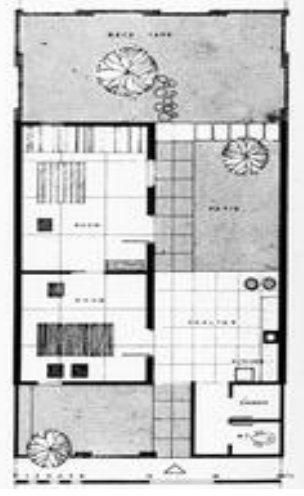

FIG. 4(a). SKETCH PLAN OF A LOW RISE HOUSE

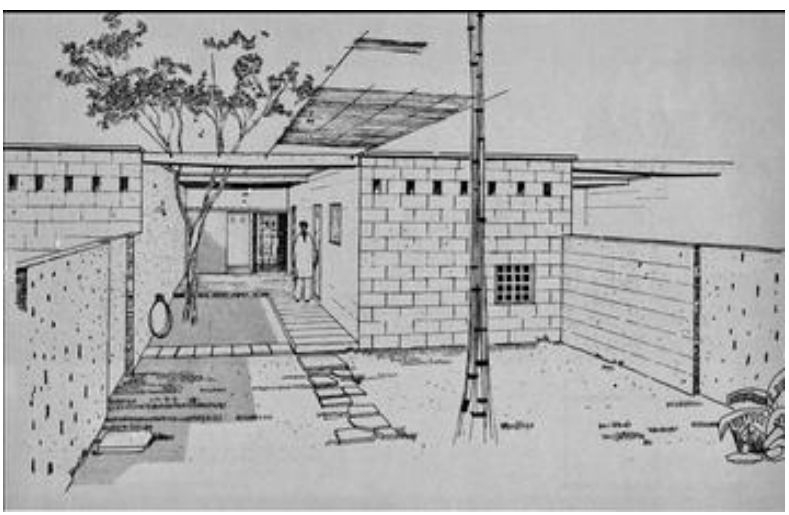

FIG. 4(b). VIEW OF THE INTERNAL SPACES OF THE HOUSE CENTRALIZED AROUND A COURTYARD [6]

Mehran University Research Journal of Engineering \& Technology, Volume 37, No. 1, January, 2018 [p-ISSN: 0254-7821, e-ISSN: 2413-7219] 
center surrounded by small neighborhoods, having requisite social facilities easily approachable and within walking distances of one another [10].

The plan of the gossip square displayed in Fig. 5(a), shows a leisure circulation of pedestrians that was further articulated by culture-specific components. Fig. 5(b), the public cum community squares were designed that were based upon the concept of culture-specific architectural components and the urban spaces. Doxiadis and his team called them as the gossip squares; they were combined as a rational and modernist approach with an attention towards domestic features of interest. Interestingly mosques were planned near to the public squares being part of the group activity of people.

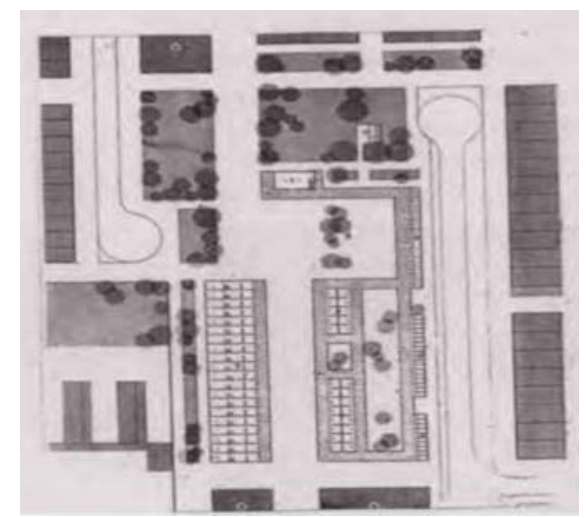

FIG. 5(a). PLAN OF THE GOSSIPS SQUARES

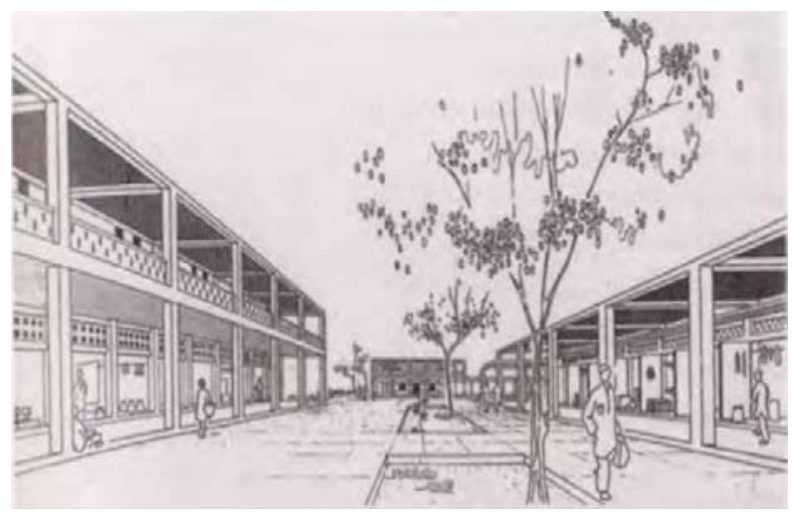

FIG. 5(b). VIEW OF GOSSIPS SQUARES - CULTURE SPECIFIC ARCHITECTURAL COMPONENTS AND URBAN SPACES [6]
In addition to the presence of gossip squares, the most attention-grabbing aspect was the contemporary yet traditional design of the marketplaces. Doxiadis reconceptualized the marketplaces as oriental souks and covered bazaars as shown in Fig. 6(a-b). That not only expressed Doxiadis's sensitivity towards the contemporary modernist approach but his vision for the contextual planning.
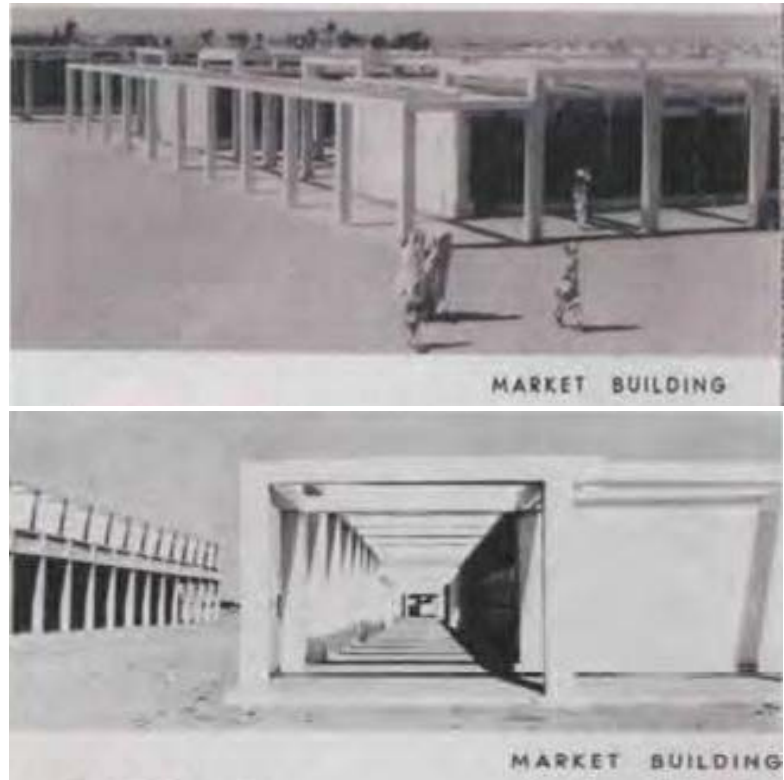

FIG. 6(a). TOP AND BOTTOM) REALIZATION OF THE RE CONCEPTUALIZED MARKETS IN FORM OF SOUKS

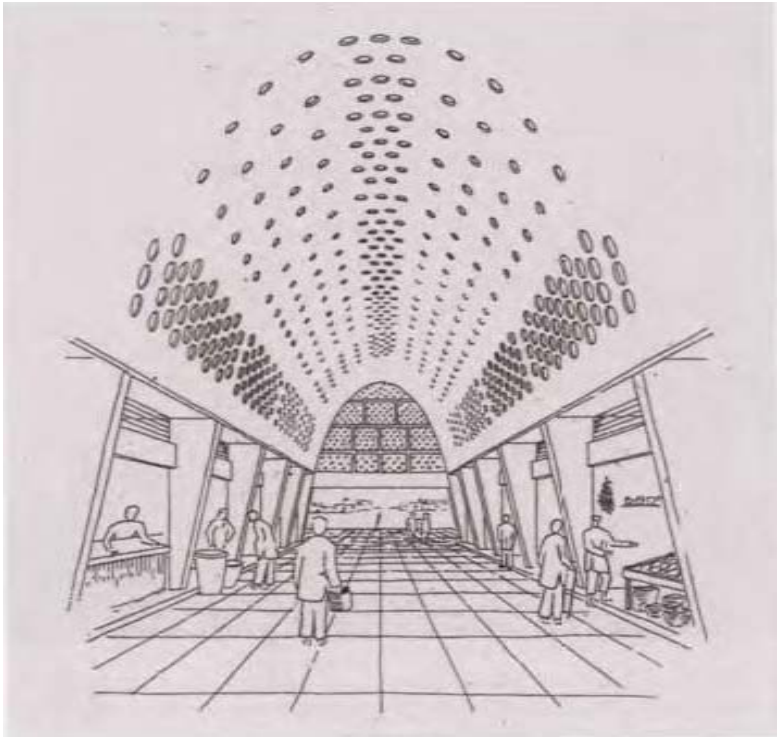

FIG. 6(b). SKETCH OF THE COVERED MARKETPLACE [6]

Mehran University Research Journal of Engineering \& Technology, Volume 37, No. 1, January, 2018 [p-ISSN: 0254-7821, e-ISSN: 2413-7219] 
Dwellers were not only facilitated by this service but they took pleasure in the idea of shopping and relaxing under covered shade. In his planning provision of communitysquares, hammams and mosques, covered markets with roofs reminiscent of the traditional souks and schools etc. were all inspired by the culture oriented attributes. These markets were supposed to subsidize the construction and maintenance costs so that they could be occupied by the low income class residing in the area. Though the shops remained unoccupied till today but new informal markets established via encroaching the area proposed for the other activities in the initial plan. Most of the main arteries were occupied for the commercial purpose.

Fig. 7 the schools were designed on the basis of courtyard planning with open spaces in the center that were supposed to be used as play areas. However, each of the zones was provided with a park and leisure activity areas for children.

Inspired by the local functional and architectural features, Doxiadis installed wind catchers on top of each school roofs with their mouth positioned to catch maximum amount of wind that was further channelized to the class rooms The walls of the classes were constructed of the perforated concrete screens similar to the ones used in the houses for better ventilation practices [9].

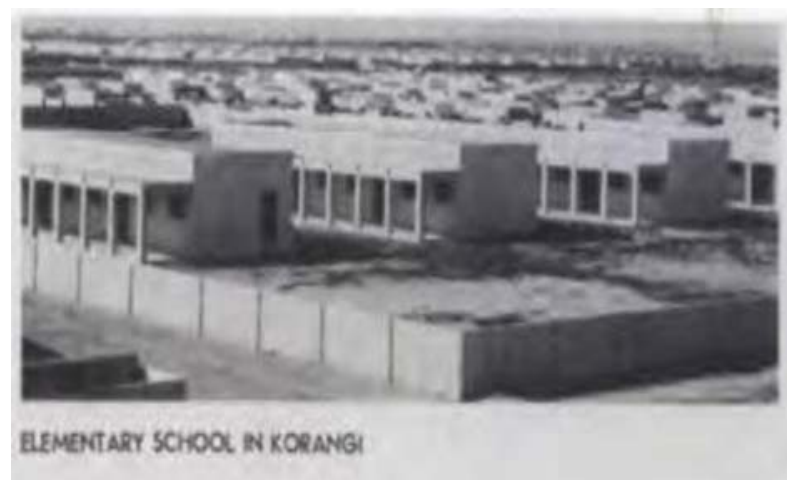

FIG. 7. IMAGE OF THE MODEL ELEMENTARY SCHOOL IN KORANGI [6]
Apart from schools dispensaries were also constructed as part of the towns but not developed on their actual allocated location. Due to haphazard encroachment the facilities such as dispensaries and the schools were opened as the commercial enterprises in the houses in total contradiction of the Doxiadis plan.

\subsection{Shelving of the Doxiadis Plan}

Government soon realized from problems in the Korangi that the matter of wiping city center cleans from the poor was more than a social problem and involved finances. Soon after the initiation of the project, the plan failed to achieve its targets and was shelved, affecting the whole city. Origin of Korangi was basically the beginning of poor-rich segregation in Karachi by pushing society's weakest members toward the periphery [11].

The government provided houses to families on a rentto-own basis and the rental payments were supposed to help finance the construction of further houses and so on. Growth in the industrial areas did not happen at the estimated pace. Thus recovery from users was very low. With unavailability of employment people were not able to afford suburban living, even with the government subsidies. It became nearly impractical to continue development of schemes in case of no return from the dwellers. The government was also unable to generate revenue from its own finances. As a result of failure to pay, eviction of hundreds of families from their houses occurred. Those who stayed back were subjected to financial difficulties such as unemployment and commuting issues to squat in the city center so as to be nearer to their work places and sold their homes to speculators, which were further resold.

Mehran University Research Journal of Engineering \& Technology, Volume 37, No. 1, January, 2018 [p-ISSN: 0254-7821, e-ISSN: 2413-7219] 


\subsection{Repercussion of the Plan}

\subsubsection{Development of Informal Settlements}

The concern of squatter settlements appeared as the result of the failure of developing self-sufficient satellite towns in the fringes of the city. Most of the people moved back to the city and the ones who stayed started building unauthorized shacks in Korangi somewhat similar to what government had been trying to demolish in the central city. As the result of these large evictions the issue of development of illegal subdivisions occurred in Karachi. It became nearly impossible for the poor to obtain land in the city center [12]. Thus they started an illegal practice of subdividing land on the city peripheries in consolidation of what came to be known as the informal sector in housing. These informal settlements evolved into slums / squatters near the satellite towns and put burden on their infrastructure and the transport facilities.

\subsubsection{Transportation Expenses}

Transportation became another immense concern that arose due to the non-availability of proper road network connecting Korangi to the inner center. Each day trucks packed with people rode between Korangi and the city center. A great number of people had to travel every day, changing three buses from Korangi and rest of outskirts of Karachi to work in city center and nearby areas.

Only the poorest people were being moved out of the city center and the transportation costs added more to their monthly expense. Some of them could not even afford the bus fares. Instead of becoming self-sufficient citizens, the resettlement resulted in an increase in their expenses and the long commuting time for them. Being frustrated from the huge travelling time and the fares people start moving back to the city centers. They built new huts in the same neighborhoods that the government was working so hard to clear.

\subsubsection{Vandalism to the City's Urban Fabric}

New cooperative housing societies and the satellite towns for the working class refugee population established at the extended limits of the city deprived the historic center of its elite class population as more influential and wealthier families in the refugee colonies shifted to those colonies leaving behind the historic buildings occupied by them earlier. The colonies were somehow connected to the inner city and most of the residents had their own transportation facility but the working class who was only dependent on the public transport was left with no vehicular compensation. Since there was no proper transportation network, the whole movement went through Saddar. This transformed Saddar into a transit camp, congested with people, badly maintained busses and badly maintained traffic [13]. It badly affected Saddar's role as the center for cultural and the intellectual life in Karachi.

The city grew outward for residential purpose, at the same time it grew inward with the working class people moving back to the city. They occupied the uninhabited structures and started to develop informal shelters. Moreover the major whole sale markets located within the city center extended their limits over time. As there was no more space for their extension they eventually occupied the historic structures and converted them into godowns and storages etc.

Not only this but the constant population growth with increasing economic pressures and the least economic incentives exerted pressure on the buildings in order to fulfill the requirements of the dwellers, and under the inadequate law enforcement, the situation resulted in the poor state of conservation of the architectural heritage in the city.

Mehran University Research Journal of Engineering \& Technology, Volume 37, No. 1, January, 2018 [p-ISSN: 0254-7821, e-ISSN: 2413-7219] 


\subsection{Current Status of the Korangi Town}

At the moment the satellite town of Korangi is one of the 18 municipal towns of Karachi with further subdivision of 9 union councils. Due to the prime location near seashore, the area now is surrounded by high end golf courses, port and a naval base that subject it towards high pressure of gentrification (Fig. 8).

The current status of the town is in contrast of how it was planned and totally contradictory to the vision of Doxiadis. Coping with the situation and for the reason of accommodating the growing financial needs, the original planning has been altered to a greater extent. Korangi's street grids are now filled with squatter homes even the open backyards of the houses have built structures now. A very handful of the actual climate oriented houses are existing but in an immense altered form even unrecognizable. Rest would have been subjected to the high market pressure and probably demolished to be replaced by the high rise structures over the period of time. Due to the rapid changes in demographic patterns of the region, the area is subjected to the high demand for housing. The concept of low-rise, high-densified settlements have transformed into high-rise high-densified settlements, creating an awful impact on the existing infrastructure. Most of the high rise housing blocks are constructed of hollow concrete blocks that are not environment friendly and react with the heat. No specific architectural style or pattern is followed. Korangi was supplied water through limited channels at the time of its establishment, now water is provided through tankers, which is not at all economical.

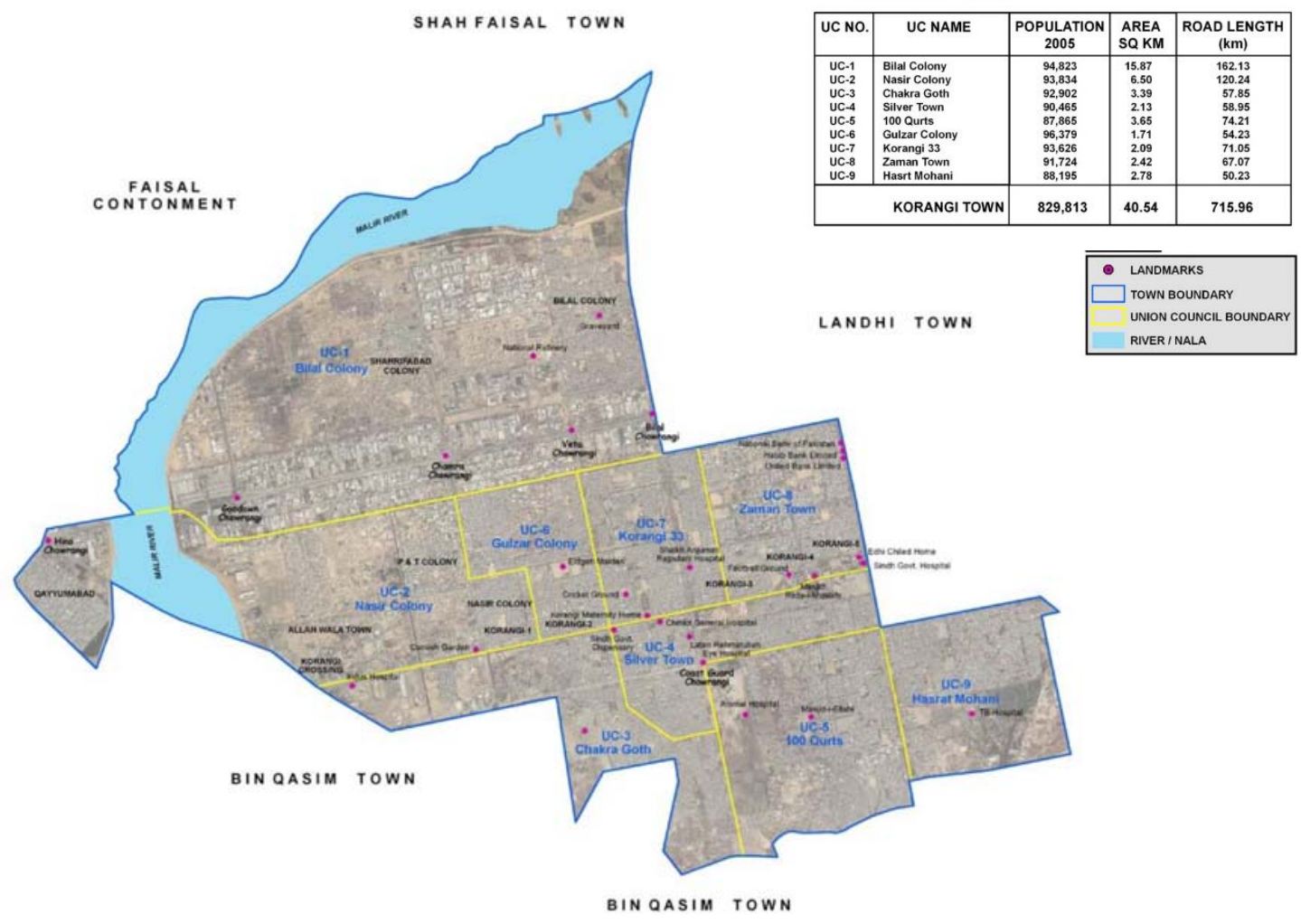

FIG. 8. CURRENT MAP OF SATELLITE TOWN OF KORANGI TOWN WITH ITS 9 UNION COUNCILS [14]

Mehran University Research Journal of Engineering \& Technology, Volume 37, No. 1, January, 2018 [p-ISSN: 0254-7821, e-ISSN: 2413-7219] 
In Doxiadis plan not only the houses were designed as climate friendly but also the schools were specially designed to catch maximum air via wind catchers. Unfortunately they are also no longer surviving as shown in Fig. 9(a-b). The concept of centralized market place is not functioning rather people turned markets into their homes. Ground floors of the homes are transformed into shops. The low rise dense district is transformed into a multi storied high densified neighborhood. Secondary streets are encroached. Though, the main roads are wide and less encroached providing less traffic congestion as compared to the inner city center.

Sense of zoning is erased; mosques and the dispensaries are built in a location nobody had planned. Schools,

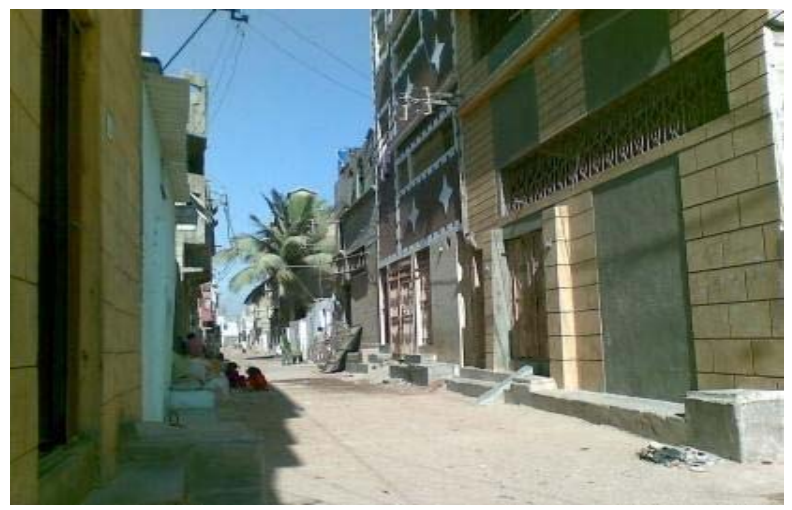

FIG. 9(a). GENERAL VIEW OF A NARROW STREET

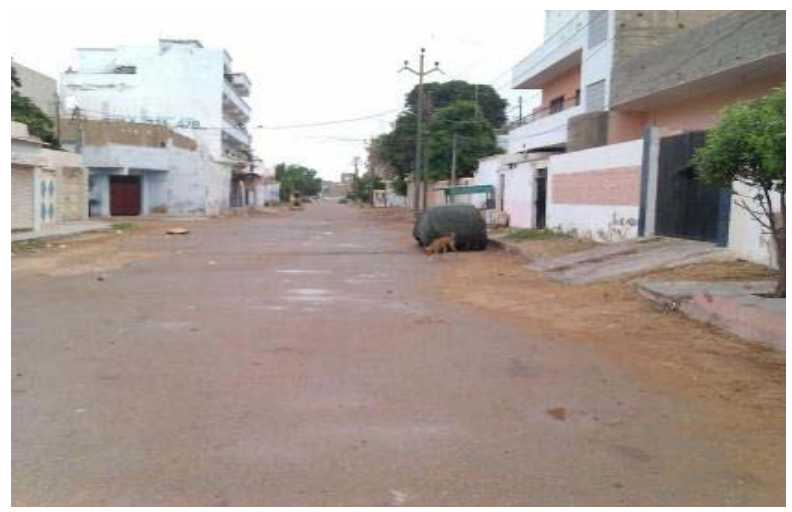

FIG. 9(b). WIDER ROAD DEPICTING DIFFERENT BUILDING HEIGHTS [14] dispensaries and markets were constructed as part of the schemes. These, especially the markets, were supposed to subsidize the maintenance of the township. Fig. 10(ab), communal spaces such as parks and sports areas are abandoned and not maintained at all. However the centralized children parks to some extent are still existing and very well used by the inhabitants.

General cleanliness is also an issue as evident from Fig. 11(a-b). Main roads and the streets are filled with garbage disposals which lead to the environmental degradation. Area is managed under a municipal bureau that is responsible for this issue.

Industrial Area of Korangi nevertheless, got operational in 1970s, a decade after its establishment and now has

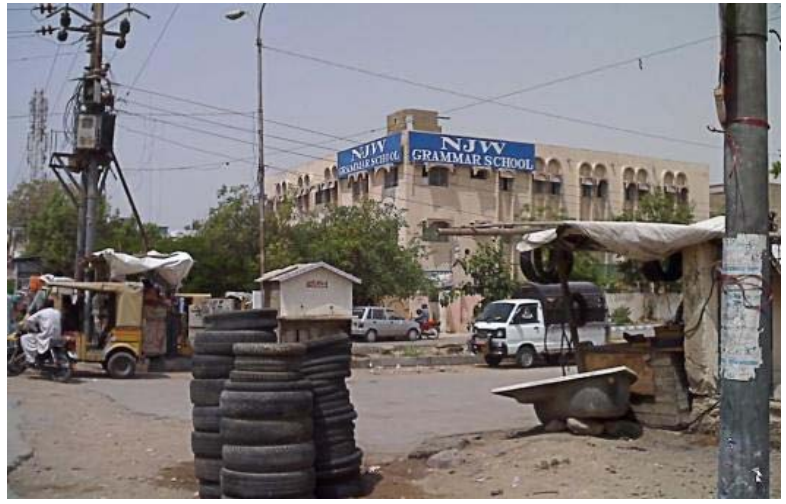

FIG. 10(a). GENERAL VIEW OF A SCHOOL BUILDING

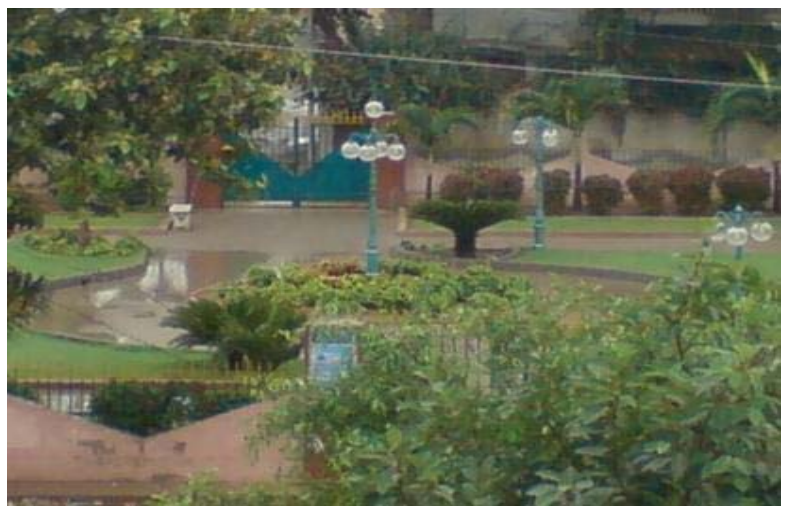

FIG. 10(b). A VIEW OF CHILDREN PARK [14]

Mehran University Research Journal of Engineering \& Technology, Volume 37, No. 1, January, 2018 [p-ISSN: 0254-7821, e-ISSN: 2413-7219] 
become one of the largest industrial estates of Pakistan. stretched over approximately 8500 acres, has multiple industries such as textiles, jute, wool, leather, pharmaceuticals, cosmetics, sanitary, chemicals, engineering, rubber products, paint, oil refineries, food, automobiles industries and many more [15].

Providing employment to more than hundred thousands of workers is one of the major attractions for the rural urban migration. For the sake of work, people migrate from rural areas to Karachi and end up in Korangi. The recent urban development in the area in form of high rise structures is the result of high demand for housing, which keeps increasing due to these migrations and the changing demographics.

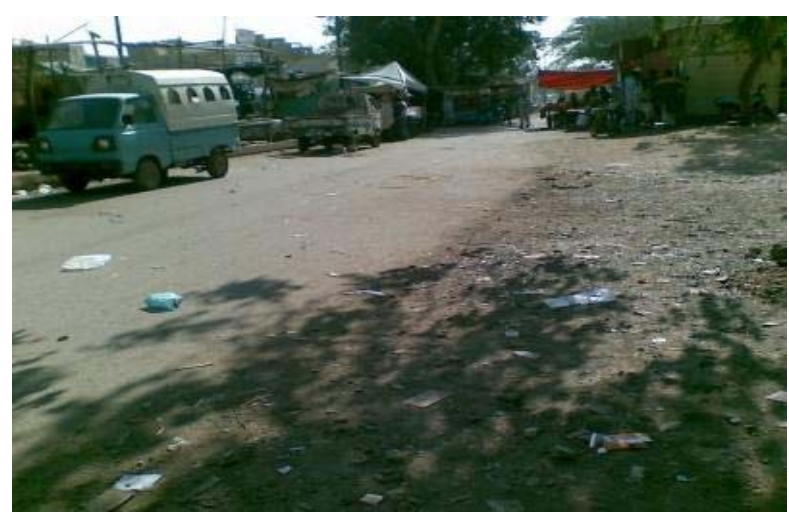

FIG. 11(a). GENERAL VIEW OF A NARROW STREET

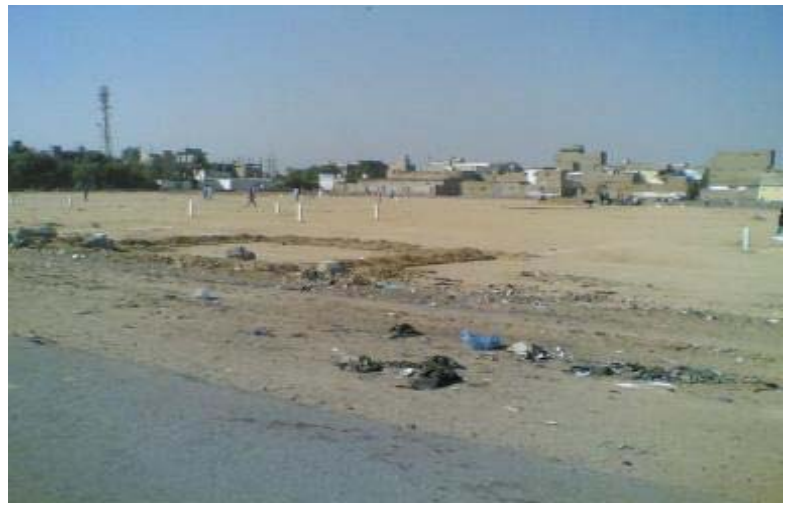

FIG. 11(b). VIEW OF WIDER ROAD SHOWING GENERAL CONDITION OF CLEANLINESS [14]

\section{CONCLUSION}

Korangi; a new satellite town that was meant to be a major urban regeneration project in post-independence Karachi failed and the failure was referred to many reason. The scope of planning on its larger scale was not understood during the development process to relate to grass root and the emerging realities of Karachi in late 50s and early 60s. Inspiration of planning standards and the policies was basically taken up from the first world regulations and experiences that were incompatible with the local cultural, social and economic realities. The indigenous way of living and the vernacular living practices to some extent were ignored by not taking into account the individual psychology of the community for whom the town was designed. As most the planning was subjective to the surveys that established conditions but not the process and actors.

Affordability and the state's financial limitations also subjected the project towards its failure. The basic reason could be enormous amount of the money spent in making of the new capital of Pakistan, which could rather be used for the provision of basic infrastructure and services for the development of the industrial activity to the existing satellite towns. As a repercussion urban planning in Karachi was totally forgotten which eventually led to the failure of the plan and left with a permanent transportation trouble for the city.

These Projects were supposed to take into account the tangible and intangible cultural heritage of human settlements and of the communities to be living in the towns but could not meet the actual objectives. Thus this whole study reaffirms the facts that urban land use

Mehran University Research Journal of Engineering \& Technology, Volume 37, No. 1, January, 2018 [p-ISSN: 0254-7821, e-ISSN: 2413-7219] 
management, resettlement, and the up gradation of the social and cultural environment could only be achieved through a well-coordinated city master plan taking into account the current and emerging ground realities of all important stakeholders.

\section{ACKNOWLEDGEMENT}

Authors pay their gratitude to the valuable comments made by the Internal and External Referees/Experts, which helped in development of the final draft of this paper. They admire the support of Prof. Krista de Jonge, and Prof. Thomas Coomans. University of Leuven, for their guidance. Prof. Dr. Ahmed Zeb Khan, University of Leuven, Brussels Campus, for sharing documents from his personal archive and all the authors who contributed their data regarding the topic on the internet.

\section{REFERENCES}

[1] Kumar, R., "Mega City Karachi with 18 Towns Waiting for Planning and Reform”, Proceedings of Pakistan Urban Forum, Lahore, 2011.

[2] “Karachi Without a Master Plan”, Daily Dawn, Karachi, Paksitan, December 2, 2002, www.dawn.com (Last Accessed on May 8, 2014).

[3] "Karachi: Updating of Master Plans Level of Doldrums", Daily Dawn, Karachi, Pakistan, February 10, 2003, www.dawn.com, (Last Accessed on April 30, 2014).

[4] Asdar, K.A., "Cinema and the City: The Ayub Years", Daily Dawn, Karachi, Pakistan, May 05, 2013, www.dawn.com, (Last Accessed on May 8, 2014).

[5]
[6]

Pavlidou, G., "Satellite Town of Korangi”, Constantinos, A., "Doxiadis Archives Established in 1996, Constantinos Emma Doxiadis Foundation, Architects \& Urban Planners, Greece, archive.doxiadis.org, (Last Accessed on May 18, 2014).

[7] Younus, M., "Creating Synergy in the Implementation of Housing Rights Actions by Government and Civil Society: A Case Study of Karachi Pakistan”, Urban Resource Centre Karachi, www.urckarachi.org, (Last Accessed on May 1, 2014).

[8] Mahsud, A.Z.K., "Constantinos A. Doxiadis Plan for Islamabad: The Making of a City of the Future 1959-1963”, Katholieke Universiteit Leuven-Faculteit Toegepaste, Wetenschappen Printing Press, Volume I-II, [ISBN: 978-90-5682-927-8], pp. 94-98, 120, Heverlee, Belgium, 2008.

[9] Steve, I., "Instant City - Article Compilation", www.epubbud.com, (Last Accessed on May 3, 2014).

Mahsud, A.Z.K., “Constantinos A. Doxiadis Plan for Islamabad: The Making of a City of the Future 1959-1963”, Katholieke Universiteit Leuven-Faculteit Toegepaste Wetenschappen, Printing Press, Volume I-II, [ISBN: 978-90-5682-927-8], pp. 56, Heverlee, Belgium, 2008.

Hasan, A., "A Study on Metropolitan Fringe Development in Karachi, Focusing on Informal Land Subdivision - Report Prepared as part of a UNESCAP study on the Metropolitan Fringe Areas in the Major Cities of the ESCAP Region in April 1987”, www.arifhasan.org, (Last Accessed on May 8, 2014).

[13] Hasan, A., Polak, A.S., and Polak, C., "The Hawkers of Saddar Bazaar”, Ushba Publishing International, ISBN: 969858861], pp. 11, Karachi, Pakistan, 2008. 
[14] "KMC, Official Web Portal of Karachi Metropolitan Corporation”, www.kmc.gos.pk, (Last Accessed on June 5, 2014).
[15] "Karachi Association of Trade \& Industry, Representative Body of More than 4500 Industrial, Commercial and Service Units”, Korangi Association of Trade and Industry, www.kati.pk, (Last Accessed on May 20, 2014). 